Rehabilitating Bodies 



\title{
Rehabilitating Bodies
}

Health, History, and the American Civil War

\author{
LISA A. LONG
}

\section{$\overline{\text { PENN }}$}

University of Pennsylvania Press

Philadelphia 
Copyright (C) 2004 University of Pennsylvania Press

All rights reserved

Printed in the United States of America on acid-free paper

$\begin{array}{llllllllll}10 & 9 & 8 & 7 & 6 & 5 & 4 & 3 & 2 & 1\end{array}$

Published by

University of Pennsylvania Press

Philadelphia, Pennsylvania 19104-4011

Library of Congress Cataloging-in-Publication Data

Long, Lisa A.

Rehabilitating bodies : health, history, and the American Civil War / Lisa A. Long. p. cm.

Includes bibliographical references and index.

ISBN 0-8122-3748-X (cloth : alk. paper)

1. United States-History-Civil War, 1861-1865-Historiography. 2. United States-History-Civil War, 1861-1865-Health aspects. 3. United States-

History-Civil War, 1861-1865-Psychological aspects. 4. United States-HistoryCivil War, 1861-1865-Literature and the war. 5. Ontology. 6. Ontology in literature. 7. Knowledge, Theory of. 8 . Knowledge, Theory of, in literature. 9. Body, Human (Philosophy) 10. Body, Human, in literature. I. Title.

E468.5.L66 2004

2003060200

$973.7-d c 22$ 